\title{
Benthic community productivity in the Magellan region and in the Weddell Sea*
}

\author{
THOMAS BREY and DIETER GERDES
}

Alfred Wegener Institute for Polar and Marine Research, P.O. Box 120161, D-27576 Bremerhaven, Germany.
E-mail: tbrey@awi-bremerhaven.de

\begin{abstract}
SUMMARY: Our comparison of macrobenthic biomass, production and productivity of the Magellan region (14 - $349 \mathrm{~m}$ water depth) and the Weddell Sea (132 - $548 \mathrm{~m}$ water depth) is based on multi box corer samples collected in both areas. Biomass is slightly but not significantly lower in the Magellan region $\left(7.3 \mathrm{~g} \mathrm{C} \mathrm{m}^{-2}\right)$ than in the Weddell Sea $\left(12.0 \mathrm{~g} \mathrm{C} \mathrm{m}^{-2}\right)$. Annual production and P/B ratio are higher in the Magellan region $\left(5.1 \mathrm{~g} \mathrm{C} \mathrm{m}^{-2} \mathrm{y}^{-1}, 0.7 \mathrm{y}^{-1}\right)$ as compared to the Weddell Sea $\left(3.6 \mathrm{~g} \mathrm{C} \mathrm{m}^{-2} \mathrm{y}^{-1}, 0.3 \mathrm{y}^{-1}\right)$. In the Magellan region, Mollusca, Polychaeta and Arthropoda dominate benthic production, whereas in the Weddell Sea Polychaeta, Porifera and Echinodermata are the most productive taxa.
\end{abstract}

Key words: zoobenthos, productivity, Antarctica, Magellan region.

RESUMEN: PRoductividad de La COMUnidad bentónica en la Región Magallánica y en el Mar de Weddell. - Nuestra comparación de biomasa, producción y productividad macrobentónica de la región de Magallanes (14 - 349 m) y del Mar de Weddell (132 - $548 \mathrm{~m}$ ) se basa en las muestras recogidas con multi box-corer en ambas áreas. La biomasa es levemente, pero no significativamente, más baja en la región de Magallanes $\left(7,3 \mathrm{~g} \mathrm{C} \mathrm{m}^{-2}\right)$ que en el Mar de Weddell $\left(12,0 \mathrm{~g} \mathrm{C} \mathrm{m}^{-2}\right)$. La producción anual y la tasa $\mathrm{P} / \mathrm{B}$ son más altas en la región de Magallanes $\left(5,1 \mathrm{~g} \mathrm{C} \mathrm{m}^{-2} \mathrm{y}^{-1}, 0,7 \mathrm{y}^{-1}\right)$ comparadas con las del Mar de Weddell $\left(3,6 \mathrm{~g} \mathrm{C} \mathrm{m}^{-2} \mathrm{y}^{-1}, 0,3 \mathrm{y}^{-1}\right)$. En la región de Magallanes, Mollusca, Polychaeta y Arthropoda dominan la producción bentónica, sin embargo los taxones más productivos en el Mar de Weddell son Polychaeta, Porifera y Echinodermata.

Palabras claves: zoobenthos, productividad, Antártida, región de Magallanes.

\section{INTRODUCTION}

South America was the last continent to be separated from Antarctica about 25 million years ago (Arntz et al., 1994). Moreover, the actual distance between the southern tip of South America and the Antarctic Peninsula is only about $1000 \mathrm{~km}$. Hence, if we assume that there are still remains of ancient relations or even actual connections between non-

This is AWI contr. no. 1440

*Accepted October 15, 1998.
Antarctic and Antarctic benthic shelf fauna, the Magellan fauna is our prime suspect. Besides pure taxonomic relations, there could also exist similarities at the level of community structure (e.g. taxonomic composition, feeding guilds) or community dynamics (e.g. reproductive strategies, growth patterns, energy flow). Community energy flow is the focus of this study: We compare mean biomass (B), annual production $(\mathrm{P})$ and productivity $(\mathrm{P} / \mathrm{B})$ of the shelf communities of the Magellan region and the Weddell Sea in order to identify differences in these community parameters and their distribution among major taxonomic groups in either area. 


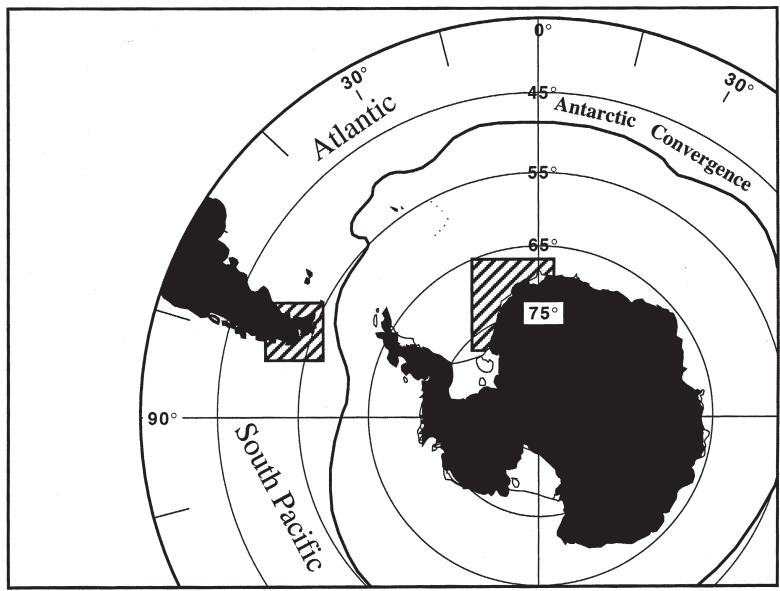

FIG. 1. - Magellan region and Weddell Sea.

\section{METHODS}

\section{Data collection and treatment}

In the Magellan region 31 stations (14 - $349 \mathrm{~m}$ water depth) were sampled in 1994 with the multi box corer (Gerdes, 1990, Gerdes et al., 1992). In the Weddell Sea 39 stations were sampled along the eastern shelf (132 - $548 \mathrm{~m}$ water depth) between 1987 and 1991 using the same corer. All samples were sieved through $0.5 \mathrm{~mm}$ mesh size and fixed in $4 \%$ formaldehyde buffered with hexamethylentetramine.

In the laboratory animals were sorted and identified to 38 taxonomic groups (Table 1), and abundance and wet mass per group were determined. We converted the wet mass data to $\mathrm{g}_{\text {org }}$ and $\mathrm{kJ}$, using conversion factors for major taxonomic groups published in Cummins and Wuycheck (1971), Dayton et al. (1974), Atkinson and Wacasey (1976), Steimle and Terranova (1985), Rumohr et al. (1987), Wacasey and Atkinson (1987), Walker et al. (1987),

TABLE 1. - The 38 taxonomic groups used for estimates of annual $\mathrm{P} / \mathrm{B}$ ratio. The numbers in brackets indicate the 12 major taxonomic groups used for data representation (Figs. 2 and 3).

$\begin{array}{lll}\text { Porifera (1) } & \text { Gastropoda (6) } & \text { Isopoda (8) } \\ \text { Hydrozoa (2) } & \text { Solenogastrea (6) } & \text { Tanaidacea (8) } \\ \text { Anthozoa (2) } & \text { Scaphopoda (6) } & \text { Ostracoda (8) } \\ \text { Bryozoa (3) } & \text { Polychaeta (7) } & \text { Crustacea spp. (8) } \\ \text { Brachiopoda (3) } & \text { Oligochaeta (7) } & \text { Echinoidea (9) } \\ \text { Sipunculida (4) } & \text { Hirudinea (7) } & \text { Holothuroidea (9) } \\ \text { Turbellaria (5) } & \text { Echiurida (7) } & \text { Asteroidea (9) } \\ \text { Nemertinea (5) } & \text { Acari (8) } & \text { Ophiuroidea (9) } \\ \text { Priapulida (5) } & \text { Pantopoda (8) } & \text { Crinoidea (9) } \\ \text { Vermes spp. (5) } & \text { Amphipoda (8) } & \text { Hemichordata (10) } \\ \text { Polyplacophora (6) } & \text { Cumacea (8) } & \text { Tunicata (11) } \\ \text { Aplacophora (6) } & \text { Harpacticoidea (8) } & \text { Unidentified (12) } \\ \text { Bivalvia (6) } & \text { Cirripedia (8) } & \\ \end{array}$

Brey et al. (1988), Dauvin and Joncourt (1989), Barthel (1995) and references therein.

\section{Estimation of annual production/biomass ratio and production}

Brey et al. (1996) estimated population P/B ratio from easy-to-obtain parameters such as mean body mass, living mode, feeding type, taxon, water depth and temperature by means of artificial neural networks, which are a specific multivariate non-linear approach. Production was estimated from P/B and population biomass. Brey et al. (1996) showed the sum of population production values obtained by this approach to provide a reasonable estimate of community production. Owing to the extremely large number of species present in the Antarctic samples, we were not able to work at species level, but instead used the 38 taxonomic groups of Table 1 for both Magellan and Weddell Sea samples. For these groups we determined the parameters mentioned above and used the artificial neural networks of Brey et al. (1996) to estimate $\mathrm{P} / \mathrm{B}$, and, in combination with mean biomass, production per group. The sum of these values resulted in community production.

\section{RESULTS}

Results are presented at the level of 12 major taxonomic groups and the community (Figs. 2, 3). Biomass is slightly but not significantly $(\alpha=0.10)$ lower in the Magellan region $\left(7.3 \mathrm{~g} \mathrm{C} \mathrm{m}^{-2}\right.$, S.D. \pm 9.9) than in the Weddell Sea (12.0 $\mathrm{g} \mathrm{C} \mathrm{m}^{-2}$, S.D. \pm 19.7). In the Magellan region, Mollusca, Arthropo-

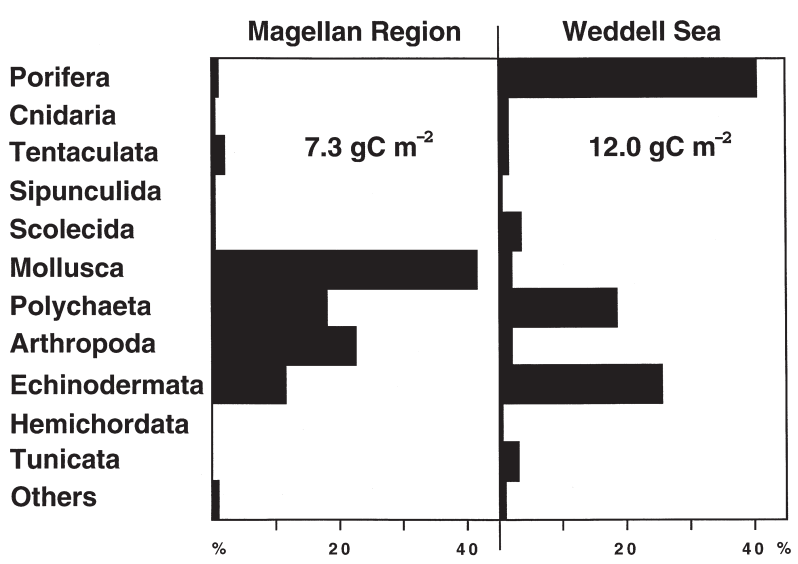

FIG. 2. - Macrobenthic biomass $\left(\mathrm{g} \mathrm{C} \mathrm{m}^{-2}\right)$ in the Magellan region and in the Weddell Sea. 


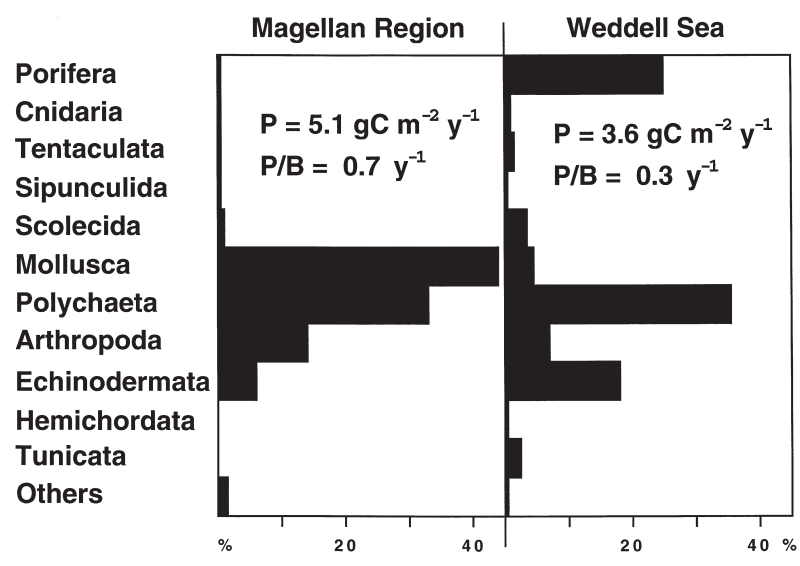

FIG. 3. - Macrobenthic production $\left(\mathrm{g} \mathrm{C} \mathrm{m}^{-2} \mathrm{y}^{-1}\right)$ and productivity $\left(\mathrm{y}^{-1}\right)$ in the Magellan region and in the Weddell Sea.

da and Polychaeta contribute most (91\%) to benthic biomass. In the Weddell Sea, Porifera, Echinodermata and Polychaeta are the dominant taxa $(85 \%$, Fig. 2). Annual production and $\mathrm{P} / \mathrm{B}$ ratio amount to about $5.1 \mathrm{~g} \mathrm{C} \mathrm{m}^{-2} \mathrm{y}^{-1}$ and $0.7 \mathrm{y}^{-1}$ in the Magellan region, compared to $3.6 \mathrm{~g} \mathrm{C} \mathrm{m}^{-2} \mathrm{y}^{-1}$ and $0.3 \mathrm{y}^{-1}$ the Weddell Sea. In the Magellan region, Mollusca, Polychaeta and Arthropoda contribute $>90 \%$ to community production, whereas in the Weddell Sea about $78 \%$ of community production results from Polychaeta, Porifera and Echinodermata (Fig. 3).

\section{DISCUSSION}

\section{Methods}

From a statistical point of view, the number of stations, 31 in the Magellan region and 39 in the Weddell Sea, is rather low, as indicated by the high variability of biomass data. We could not detect significant differences in biomass between the two areas, although a comparison of Antarctic with nonAntarctic biomass data based on larger data sets shows Antarctic biomass to be significantly higher (Brey and Gerdes, 1997). Moreover, in both regions we sampled only during a limited time of the year and hence cannot take into account potential annual cycles in abundance and biomass.

Sampling by the multi box corer (MBC) is likely to underestimate abundance and biomass of large but comparatively rare species as well as of motile species. By combination of data from MBC, trawls, and photo surveys, Dahm (1996) showed that MBC underestimated biomass of ophiuroids by a factor of about three in the Weddell Sea. Decapods, amphipods and other highly mobile animals may be able to escape actively from being sampled by corers and grabs. In our study, however, both areas have been sampled by the same gear. Hence, the bias introduced by sampling may have affected the absolute figures of biomass and production, but not the relation between Magellan and Weddell Sea data.

The application of the artificial neural network approach of Brey et al. (1996) for estimating P/B ratios to larger taxonomic groups (Table 1) may have caused a decrease in accuracy of the estimates of community productivity and production.

\section{Productivity and production}

Our results indicate that the benthos of the Magellan region shows higher production $\left(5.1 \mathrm{~g} \mathrm{C} \mathrm{m}^{-2} \mathrm{y}^{-}\right.$ $\left.{ }^{1}\right)$ as well as higher productivity $\left(0.7 \mathrm{y}^{-1}\right)$ than the benthos of the Weddell Sea $\left(3.6 \mathrm{~g} \mathrm{C} \mathrm{m}^{-2} \mathrm{y}^{-1}\right.$ and $\left.0.3 \mathrm{y}^{-1}\right)$, whereas biomass is not distinctly different. Better food supply to the benthos and/or higher ambient temperature may be responsible for higher production and productivity of the Magellan benthos (see Brey and Clarke, 1993).

The distribution of benthic production among major taxonomic groups is distinctly different between the two areas. In the Magellan region 97\% of production is concentrated on four groups only (Mollusca, Polychaeta, Arthropoda, Echinodermata), whereas in the Weddell Sea nine groups are required to reach $97 \%$ of community production (Fig. 3). In other words, in terms of major taxonomic groups, energy flow through the benthos is more "diverse" in the Weddell Sea.

Mollusca are the group with highest production in the Magellan area, but do not play any significant role in the Weddell Sea. Vice versa, Porifera and Echinodermata contribute significantly to production in the Weddell Sea, but not at all in the Magellan region. Polychaeta are the only group of similar high importance in both areas $(>=33 \%)$. Obviously, about two thirds of total energy flow is channeled through different taxonomic pathways in the two areas. The reasons for these differences, especially the predominance of Mollusca in the one case and of Porifera in the other, are not yet fully understood.

Our findings indicate that concerning community structure and dynamics the Magellan benthos is more closely related to other, e.g. boreal shelf communities than to the Weddell Sea (see Brey and Gerdes, 1997). The typical features of the Antarctic 
shelf benthos are the broad distribution of energy flow among taxa and the outstanding significance of Porifera and Echinodermata in community energy flow.

\section{REFERENCES}

Arntz, W.E., T. Brey and V.A. Gallardo. - 1994. Antarctic zoobenthos. Oceanogr. Mar. Biol. Ann. Rev., 32: 241-304.

Atkinson, E.G. and J.W. Wacasey. - 1976. Caloric values of zoobenthos and phytobenthos from the Canadian Arctic. Fish. Mar. Serv. Techn. Rep., 632: 1-23.

Barthel, D. - 1995. Tissue composition of sponges from the Weddell Sea, Antarctica: not much meat on the bones. Mar. Ecol. Prog. Ser., 123: 149-153.

Brey, T., H. Rumohr and S. Ankar. - 1988. The energy content of macrobenthic invertebrates: General conversion factors from weight to energy. J. Exp. Mar. Biol. Ecol., 117: 271-278.

Brey, T. and A. Clarke. - 1993. Population dynamics of marine benthic invertebrates in Antarctic and subantarctic environments: are there unique adaptations? Antarct. Sci., 5: 253-266.

Brey, T. and D. Gerdes. - 1997. Is Antarctic benthic biomass really higher than elsewhere? Antarct. Sci., 9: 266-267.

Brey, T. and D. Gerdes. - in press. High Antarctic macrobenthic community production. J. Exp. Mar. Biol. Ecol.,

Brey, T., A. Jarre-Teichmann and O. Borlich. - 1996. Artificial neural network versus multiple linear regression: predicting P/B ratios from empirical data. Mar. Ecol. Prog. Ser., 140: 251256.
Cummins, K.W. and J.C. Wuycheck. - 1971. Caloric equivalents for investigations in ecological energetics. Int. Ass. theor. appl. Limnol. Comm., 18: 1-158.

Dahm, C. - 1996. Ökologie und Populationsdynamik antarktischer Ophiuroiden (Echinodermata) (Ecology and population dynamics of Antarctic ophiuroids). Ber. Polarforsch., 194: 1-289.

Dauvin, J.-C. and M. Joncourt. - 1989. Energy values of marine benthic invertebrates from the Western English Channel. $J$. Mar. Biol. Ass. U.K., 69 589-595.

Dayton, P.K., G.A. Robillard, R.T. Paine and L.B. Dayton. - 1974. Biological accommodation in the benthic community at McMurdo Sound, Antarctica. Ecol. Monogr., 44: 105-128.

Gerdes, D. - 1990. Antarctic trials of the multi-box corer, a new device for benthos sampling. Polar Rec., 26: 35-38.

Gerdes, D., M. Klages, W.E. Arntz, R.L. Herman, J. Galéron and S. Hain. - 1992. Quantitative investigations on macrobenthos communities of the southeastern Weddell Sea shelf based on multibox corer samples. Polar Biol., 12: 291-301.

Rumohr, H., T. Brey and S. Ankar. - 1987. A compilation of biometric conversion factors for benthic invertebrates of the Baltic Sea. Baltic Mar. Biol. Publ., 9: 1-56.

Steimle, F.W. and R.T. Terranova. - 1985. Energetic equivalents of marine organisms from the continental shelf of the temperate Northwest Atlantic. J. Northwest Atlantic Fish. Sci., 6: 117-124.

Wacasey, J.W. and E.G. Atkinson. - 1987. Energy values of marine benthic invertebrates from the Canadian Arctic. Mar. Ecol. Prog. Ser., 39: 243-250.

Walker, M., P.A. Tyler and D.S.M. Billett. - 1987. Organic and calorific content of body tissues of deep-sea elapsoid holothurians in the northeast Atlantic Ocean. Mar. Biol., 96: 277-282.

White, M.G. - 1984. Marine benthos. In: R.M. Laws (ed.), Antarctic Ecology, Vol. 2, pp. 421-461. Academic Press, London. 